\title{
СПІВВІДНОШЕННЯ ФІЛОСОФІї ТА МИСТЕЦТВА: СУЧАСНИЙ КОНТЕКСТ
}

\section{О.П. Наконечна}

Дослідження співвідношення філософії та мистецтва має значну традицію і пов'язане як із загальнокультурним процесом становлення цих типів духовної культури, так і з особливостями світоглядних пошуків в кожну історичну епоху. Тому дослідження їх взаємозв'язку не втрачає своєї важливості протягом всієї історії розвитку людської культури, однак інтерес до цієї проблеми загострюється в кризові або переломні моменти самоусвідомлення людиною себе, пошуку найбільш адекватних засобів такого усвідомлення. Тож зростання інтенсивності обмінних процесів між філософією та мистецтвом в прагненні охопити весь спектр і повноту буття сучасної людини і світу, з одного боку, та особливості їх самовизначення в реаліях (і кризі) духовного стану сучасної культури, з іншого, обумовлює актуальність теми.

Метою статті $є$ виявлення теоретичних і практичних аспектів взаємодії філософії та мистецтва як певних типів духовності, осмислення ïх особливої ролі в світоглядних пошуках сучасної людини, формуванні нової світоглядної парадигми.

Концептуальна логіка даного дослідження опирається на методологічні принципи постнекласичної раціональності, синергетики, постонтології та життєвого світу.

Взаємозв'язок філософії та мистецтва ставав предметом аналізу багатьох мислителів, зокрема, концептуальний підхід ми знаходимо у Гегеля. Та саме у романтиків проблема відношення філософської мудрості та художнього пізнання постає однією з центральних (Ф. Шлегель, Новаліс) та пов'язується з розвитком духовності людини. Порівнюючи можливості науки, філософії, моралі і мистецтва у гармонізації люд-

Актуальні проблеми духовності 
ського світовідношення, Ф. Шеллінг надає перевагу мистецтву, обгрунтовуючи думку, що мистецтво є вищим продуктом духовної діяльності людини, а виражена в ньому краса виступає критерієм істини і добра, оскільки мистецтво здатне виражати людину цілісно, а його філософське пізнання сприяє розкриттю найглибших підвалин людського духу.

Певну спадкоємність ідей романтиків ми зустрічаємо і в подальшому західноєвропейському філософсько-естетичному контексті XIX i XX століть (Т.Адорно, А.Бергсон, Г.Гадамер, М. Хайдеггер, Ф. Ніцше, А.Шопенгауер, Р. Рорті), який спричинив переосмислен-

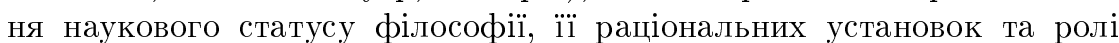
в людській життєдіяльності, а також зростання ролі чуттєвої культури в людському житті і спрямування естетики до самовизначення, самостійності. Такі шукання (М. Дюфрен, Ж.-Ф. Ліотар, Е. Морен, П. Сансо) виразилися в прагненні надати естетиці власної нормативності через потяг, з одного боку, до реального вивчення естетичних явищ, а з іншого - до ототожнення філософського міркування з художнім баченням світу, оскільки перед філософією ставиться завдання: займатись живою чуттєвою людиною.

Заслуговує на увагу позиція Т. Адорно, який, спираючись на засади негативної діалектики, розробляє принципи естетичної раціональності та констелятивної взаємодії. Метод констеляції виступає як образ «неметодичного методу», «непонятійного поняття», «визначеної невизначеності», як визнання множинності самостійних логічних центрів, мислительних ліній, що утворюють багатозначні зв'язки. Таким чином всезагальне і особливе, суперечливість чуттєвості і понятійності розглядаються не як логічні структури наукового пізнання, а передусім як фундаментальні виміри людського способу буття. Ці принципи сприяють примиренню і ненасильницькому синтезу одиничного і всезагального, міметичного і раціонального, духу і чуттєвої безпосередності, де індивідуальне людське буття, не подавлене всезагальним, може заявити про себе понятійною мовою, не втрачаючи своєї безпосередності. Використовуючи ці принципи як методологію, Т. Адорно обгрунтовує, що філософія і мистецтво зближуються в своєму істинному змісті, оскільки естетичне виступає конститутивною домінантою людського буття в його повсякденному й історичному вимірах, стверджуючи самоцінність і свободу вибору людського життя в його самоздійсненні.

Історія розвитку філософії та мистецтва, таким чином, - це становлення їх як феноменів культури, типів духовності, в яких осмислюється світоглядне відношення «людина-світ» як основа самопізнання і 
самовизначення людини. Взаємовпливи філософії та мистецтва здійснювалися протягом всієї культуро-творчої діяльності людини, однак теоретичність філософської рефлексії опиралась в своєму дискурсі на практику мистецтва поряд з наукою, мораллю, релігією, політикою. Мистецтво ставало об'єктом теоретичного аналізу в рамках естетики як філософської науки, в якій переважно використовувалися ті філософські підходи, що спиралися на засади класичної раціоналістичної європейської парадигми. Тому переосмислення взаємозв'язків філософії та мистецтва здійснюється як через розгортання духовного змісту мистецтва, так і шляхом самовизначення естетики, набуття нею самостійного статусу. Вважаємо, що в значній мірі саме завдяки взаємодії з естетикою, мистецтвом, та зверненню до практичних проблем людини філософія змогла здолати свій кризовий стан, перейти від абстрактнометафізичної методології до розробки феноменологічного, структуралістського, герменевтичного методів та констелятивного поєднання їх в осягненні проблем людини, цінностей, культури. Занурення в людське буття в усій його різноплановості набуває глибинного значення для самих філософських систем.

Внутрішня диференціація, логіка прояву різних напрямів і форм філософії та мистецтва, взаємозв'язків між ними обумовлена розумінням людини, зміною форм її світовідношення, проблемами ціннісного, духовного самоусвідомлення людства. Способом взаємовідносин філософіï та мистецтва стає діалог про людину в її життєтворчості: осмислення глибин людської духовності і різноякісності творчих можливостей людини в її відповідальному ставленні до універсуму і до самої себе. «Живе» взаємне відношення, що поєднує різні людські вияви, закріплюється в конкретних формах світоставлення й життєставлення, осягнення яких здійснюється і філософією, і мистецтвом.

При цьому ми розуміємо філософію як тип духовності, універсальний спосіб самоусвідомлення і самовизначення людини в світі через відшукування граничних засад людського буття. Тому філософія, завдяки розвитку рефлексивно-критичної здатності людини і смислотворчості, сприяє «вибудовуванню» людини і культури. «Філософія прокладає стратегічні траси людського самобудівництва, є смислотворчістю життя в її надіях, безнадійності та суперечності, тобто виступає як літургія смислу», - влучно характеризує здатність філософії до постановки вічних проблем С. Кримський $[5$, с.9].

Особливістю природи мистецтва $є$ його художньо-образність, символічність, індивідуальність в сприйнятті та осягненні людського буття. Саме завдяки своїй образності мистецтво здатне до ширшого і 
глибшого, ніж інші духовні форми, охоплення дійсності і людського ставлення до неї, бо поняття, як вважає Новаліс, є лише незрілим образом. Символічна природа мистецтва, з одного боку, вказує на його творчу суть, непристосовництво до «цього» світу, а з іншого - стверджує автономність краси, її особливу роль в життєвому світі людини. Мистецька фантазія через художній образ здатна до уявного подолання суперечностей реального життя завдяки можливості перенестися в будь-яку епоху і отримати радість та насолоду від згоди з собою. Унікальна особливість мистецтва, на думку Г. Гадамера, пов'язана з тим, що в ньому «відбувається зустріч з особливим і з проявом істини лише в одиничному» [3, с. 304].

Важливим, в цьому контексті, $\epsilon$ розгляд М. Хайдеггером художнього творіння як «стояння в самому собі», як вибудовування себе у власному бутті, як відкриття і розгортання свого власного світу, що робить цей світ подією, спів-буттям, здобуттям і здійсненням істини через невичерпну глибину його смислів. Саме так художній твір запрошує людину до здійснення можливості здобуття істини буття, а отже, й самої себе у власній суті.

Неупередженість мистецького бачення розкриває здатність митця заглянути під спід, виворіт раціональної картини світу, поставивши під сумнів однозначність вироблених стереотипів бачення світу і людини. Мистецтво здатне до деконструкції традиційних цінностей шляхом відкидання, руйнування порожніх знаків суспільного буття, симулякрів, що долає наш засадничий страх перед деструкцією, і виражає тугу людини за справжністю світу і потребу в реконструкції справжності ціннісних орієнтацій. Це сприяє конструюванню і зануренню мистецтва у архітектоніку життєвого світу з багатоманітністю тілесно-соматичних станів людини, з осягненням власного життєвого простору i часу, взаємозв'язку земного та космічного в людському бутті. Так шляхом втілення смислоприсутності в світі витворюється цілісність життєвого світу особи та осягається нею власна ідентичність смисложиттєвого самовизначення людини.

Мистецтво і філософію постмодерністської епохи поєднує осмислення дійсно існуючих життєвих форм людського та буттєвих структур іï̈ свідомості. Вони прагнуть до перевідкриття людської суб'єктивності, не претендуючи при цьому на роль наставника і судді, не формуючи авторитарної парадигми. Життєвий світ у всій його багатовимірності i багатобарвності, самоцінності та незавершеності стає і теоретичним принципом, i «текстом в тексті» 3 нашаруванням смислів, що вимагають нескінченого прочитання, імпровізації, деконструкції. 
Більше того, саме кожна з форм (мистецтво для філософської теорії та філософська теорія для мистецтва) стає «іншим» для другої, допомагаючи їй не тільки визнати свої межі для того, щоб пізнати себе, але й стати більшою за себе, збагатити і перерости себе, заповнюючи простір, де інші форми по-своєму обмежені. Принциповою підвалиною їх взаємозв'язку у розгляді різних аспектів соціокультурного універсуму людського буття є подолання суперечності між суб'єктом та об'єктом через глибину осмислення будь-якої події як незавершеної та відкритої, а індивідуального буття як «суцільного поступання» і становлення. М.Бахтін слушно вважав, що, переживаючи предмет, виражаючи його в слові, оцінці, певній реакції, образі, ми робимо його моментом живої подієвості, невіддільної від «я», і нашого відношення до нього. Це стосується також «нероздільності і незлиття» учасників події, пов'язаних один з одним зсередини і ззовні («я» в формі «іншого» та «інший» в формі «я»). Лише на таких засадах можливе поєднання двох світів - культури та життя - «...світу, в якому об'єктивізується акт нашої діяльності, і світу, в якому цей акт одноразово справді проходить, здійснюється» [1, с. 83], що були протиставлені один одному в рамках світогляду, пронизаного монологізмом і теоретизмом.

Тому сучасні філософія і мистецтво прагнуть втілити і закріпити саму можливість існування людини в умовах множинності соціальних, культурних та пізнавальних практик, з одного боку, відмовляючись від примусовості (щодо тематики, дискурсу, стилю, ракурсу погляду на проблему тощо) у своїх творах, а з іншого - даючи змогу по-новому побачити драму людського буття, відкриваючи нові джерела незнищенності життєвого потенціалу.

Розглядаючи сучасну культуру як культуру постмодерну, вважаємо слушною думку П. Козловського, що її важливою рисою є контекстуальність як «взаємопроникнення царини життя та символізації культури в оповідальній мові знаків» [4, с.246]. Процес формування нової сукупності матеріальних і духовних умов людського життя породжує протиріччя між текстом сучасної культури та її контекстом, позбавляючи людське життя певної рівноваги і значно ускладнюючи пошук нових орієнтирів. Фундаментальні засади постмодернізму складаються через подолання дихотомій: духовне-тілесне, суб'єкт-об'єкт, чоловічежіноче, ментальне-вітальне, культурне-природне та вироблення різноманітних стратегій трансцендування, трансгресування «нарцисистського автопортрету» модерну. Можливість розвитку культури тісно пов'язана з розвитком індивідів, їх життєвих світів, тож творення контексту культури опосередковано ціннісним вибором людей в єдності 
минулого, теперішнього і майбутнього, рефлексії та діяльності, пошуку ідентичності та повноцінної комунікації.

Спрямованість на діалогічність, тяжіння до іншої точки зору, розкриття всього смислового різноманіття людської життєдіяльності об'єднує сучасну філософію та мистецтво. Вони прагнуть своїми засобами охопити людину в цілісності її емоційних, інтелектуальних, підсвідомих, інтуїтивних, активних чи пасивних проявів, щоб осягнути весь спектр й повноту місця людини в світі, їі життєставлення. Ми бачимо обмінні процеси між філософією і мистецтвом в розширенні символіки мови, образності, поглибленні асоціативності: філософічність поетичної мови та художні форми філософської рефлексії (Г. Гессе, Т. Манн, Г. Маркес, Х. Борхес, А. Камю, У.Еко, Х. Ортега-і-Гасет), що дозволяє їм відкрити різні грані і намітити багатоманітність смислів людського буття, не даючи вичерпного тлумачення. Ці взаємозв'язки, розгортаючи асоціативність та образність філософської рефлексії та художньо-образного мислення, розширюють значеннєве поле як філософії, так і мистецтва, посилюючи напругу пошуку засобів втілення людської буттєвості у всьому спектрі та повноті. Адекватною позицією філософа стає позиція «філософа-художника» (Деррида про Ніцше). Вказуючи на багатовимірність людської екзистенції, мислителі-митці залишають те невимовне, що не може бути виражене, однозначно зберігаючи відкритий простір для подальшої творчості.

На нашу думку, це важливо для світоглядних засад постмодернізму, що стверджує відсутність привілейованих дискурсів, можливість і рівноправність співіснування різноманітних індивідуальних світів та істин. Орієнтація філософського та мистецького дискурсів на ствердження людської свободи у збереженні здатності бути собою (наша спільність у винятковості кожного) веде до розширення філософського та художнього бачення світу, робить їх більш адекватними духу часу й новому відчуттю життя та виражає довіру до людини в эіi здатності шукати й знаходити в філософії та мистецтві свій істинний, неприкрашений, не спрощений образ.

Взаємозв'язок філософії та мистецтва найбільшою мірою розгортається в рамках софійного типу філософствування. Його основними векторами є:

1. Осмислення світоглядного відношення «людина-світ» через призму людини. Прагнення осягнути людину в їі цілісності, єдності емоційних, інтелектуальних і несвідомих проявів. Для філософії та мистецтва немає заборонених чи нецікавих тем, оскільки вони прагнуть віднайти засоби для включення до свого змісту всієї багатоманітності 
людського життєставлення.

2. Виявлення в художній і філософській творчості неповторної індивідуальності творця (митця, мислителя), що проявляється в проблематиці, змісті, образній мові, світоглядному спрямуванні творів. Це обумовлює буття філософії та мистецтва не тільки як буття систем, концепцій, напрямів, методів, стилів, а як буття особистостей, де не вмираючи живуть Платон, Сковорода, I. Кант, Бетховен, Гете, Т.Шевченко, Пікасо, Л. Українка, М. Мамардашвілі і багато інших, що відкривали і продовжують відкривати глибини життя і духовного досвіду людськості.

3. Розкриття багатогранності людської творчості через інтуїцію, метафори, символи, що займають значне місце в образній тканині мистецтва і мові філософського мислення.

4. Розгортання розуміння буття як історичного, в якому через діалектику минулого, теперішнього і майбутнього розкривається взаємообумовленість й драматична єдність в людському житті смислу і фактичності, вічного і минущого.

Філософія і мистецтво як типи духовності звернені до минулого, сучасного і майбутнього, що зумовило їх творчий потенціал в формуванні нових ідей, ідеалів, культури в її багатоманітності, та сприяє набуттю людиною своєї неповторності й індивідуальності. Взаємозв'язок філософії й мистецтва виражається в тому, що, з одного боку, буття філософських і мистецьких творів невіддільне від їх тлумачення і розуміння, «підлягає інтеграції» в саморозуміння кожної людини, а $з$ іншого - прирощення смислу в розумінні цих творів вимагає поглиблення особистісного виміру людини, свободи у формуванні нових смисложиттєвих інтенцій індивідів.

Здатність філософії й мистецтва ставити і пропонувати рішення проблем сенсу життя, свободи і призначення людини, гуманізму й антигуманізму, добра і зла, буття людини і людства створює поле їх перехрещення, загальних інтересів, що не заперечує їх специфіки. Важливо наголосити на теоретичності філософії, прагненні до загальної значимості її теоретично-ціннісних положень через використання методології та категоріально-понятійного апарату, застосовування і тлумачення якого опирається на значну філософську традицію.

Сучасну філософію і мистецтво зближує людський досвід «тривалого подорожування по заборонених місцях» (Ф. Ніцше) власної екзистенції. І хоча ця традиція не нова - М. Монтень, Б. Паскаль, С. Кіркегор, Ф. Ніцше, Ф. Достоєвський, М. Пруст здійснювали антропорефлексію власної екзистенції, опираючись в аналізі на певні засади нор- 
мативності (як нормальності). Важливим у таких дослідженнях була увага до людини в її суперечливості, дихотомії величного і низького, сили і слабкості, гідності й ницості, нормативного і девіантного. Однак в сучасному дискурсі девіантна поведінка набуває нового статусу як такий стан людського ніщо, що може розгорнутися у все. Взаємозв'язок мистецтва і повсякденного життя здійснюється завдяки технічним можливостям репродукування миттєвостей життя та здатності повсякдення до маніпуляції мистецькими знаками: все, що дублюється в самому собі, навіть якщо це банальна повсякденна реальність, потрапляє таким чином у площину мистецького знака і стає естетичним. «Сьогодні ж, коли реальне і уявне скипілися в одне операційне ціле,- вважає Ж. Бодрійар, - естетичний чар наявний скрізь: це вже якесь підсвідоме (на рівні шостого чуття) сприймання трюків, монтажу, сценарію, надлишкової експозиції реальности у світлі моделей, не простору продукування, а стрічки для зчитування, стрічки для кодування і декодування. . . - i реальність естетична не завдяки задуму і мистецькій дистанції, а тому, що піднесена до вторинного рівня, тому що набула вторинної потуги внаслідок упередження й іманентности коду» [2, с.127]. Естетичний поворот у сучасній культурі обумовлений увагою до чуттєвої культури людини та різноманітних способів просторово-часового сприйняття світу, що створює таку поліфонію і багатовекторність буття, осягнення якої потребує нових підходів.

Сучасна людина існує в полі «диктатури анонімної ідеології» (В. Пелевін), яка пов'язана як із закріпленими в свідомості певними векторами, стереотипами, страхами тощо, так із загубленістю в системі слів, дискурсів, гламурів, підсвідомості через відсутність таких визначених (чи визнаних) векторів. Способом обживання у світі стає споживання не тільки речей, але і вражень, культурних об'єктів, концепцій, станів розуму, вищою формою якого стає «престижне споживання напоказ в області духу», як влучно визначає цей стан В.Пелевін. Споживацтво, марнослів'я реклами, маніпулювання людськими потребами, байдужість, динамізм повсякденності, відчуження людини від людини і людини від світу, домінування чуттєвості (без чутливості) у ставленні до себе та іншого стають темами сучасного мистецтва, яке задає питання: «Чи не втратили ми здатності сприймати і приймати неповторність один одного?» Даючи різні-оптимістичні і песимістичні, індивідуалістські й конформістські, прагматичні та ідеалістичні, естетські і вульгарно-кітчеві, традиціоналістичні і модерністські - відповіді в різних видах і жанрах сучасне мистецтво як виявляє різні виміри людських пошуків та ілюзій, дихотомій людського буття, так і 
намагається їх синтезувати у «вільному стилі», на межі слів і систем, ілюзії та реальності, різних часових вимірів. Відбувається легітимація заборонених тем і проблем та рух до їх «збагненності» через сюжет, який «є актом ,збирання“- - укладання тих інгредієнтів людської дії, котрі у повсякденному досвіді лишаються різнорідними і дисонуючими», - слушно вказує П. Рікьор [6, с. 315].

Характеристика сучасного становища як кризи культури, як ситуації постмодерну, руйнування традиційних цінностей виявляє відповідальність самого людства за стан універсуму, оскільки жодна зі сфер людської життєтворчості - ні наука, ні філософія, ні мистецтво, ні релігія - не створили загальноприйнятних засад для нового світогляду. Хоча спроб як песимістичних, так і оптимістичних було достатньо, що включали в себе значний спектр думок (О. Шпенглер, П. Сорокін, М. Бердяєв, А. Швейцер). Руйнування старого - це шлях до народження нового, і його зміст залежить від реалізації здатності людини до поступання як поєднання свободи волі і усвідомленого життєствердження, благоговіння перед життям і збереження ціннісного коду культури. Оскільки прагнення людини до реалізації своїх можливостей i приводить до справжніх змін.

Всі процеси, що відбуваються в культурі, потребують розвитку людської чутливості до світу, щоб бути готовими до постійного вирішування суперечностей між свободою і тотальністю, творчістю і стереотипізацією, бути чесними посередниками між поколіннями, між сферами сучасної культурної активності й традиціями, що в них склалися. «Детрадиціоналізація» (О.Кривцун) традиції має своїм виявом можливість не дотримуватися правил, стереотипів, заборон і розвивати прагнення до вироблення нових способів орієнтації в світі, дозволяє долати традицію, що була підгрунтям тоталітарності, абсолютності прийнятих заздалегідь універсальних принципів, але одночасно ускладнює і сам процес людського пошуку, бо втрачаються критерії вибору, лінії поведінки. Осягнення цього процесу потребує розгляду його 3 різних, навіть полярних боків, що здійснює своїми засобами як філософія, так і мистецтво. Це свідчить про здатність людини й культури до самооновлення та сприяє рефлексії щодо їі нових духовних вимірів, в якій знаходить своє реальне втілення розгалуженість потреб, здібностей, змагальність духовних пошуків і відкриттів.

Філософія та мистецтво як способи смислотворчості, розкриваючи єдність природи, суспільства і людства, прагнуть допомогти людині «вписатись» у світ, а світу «вписатися» в людину в усій багатогранності їх спільного становлення і взаємовпливів. Тому завдання полягає, 
в першу чергу, в об'єднанні зусиль різних типів духовності, зокрема філософії та мистецтва, по-перше, в тому, щоб розкривати наявні проблеми, по-друге, щоб бути почутими, сприйнятими і прийнятими, потретє, щоб сприяти збереженню різноманітності людського світоставлення, утримуючи вектор людськості, духовне ядро культури.

\section{1 Бібліографія}

[1] Бахтин М.M. К философии поступка // Философия и социология науки и техники. Ежегодник. 1984-1985. - М., 1986.

[2] Бодрілр Ж. Символічний обмін і смерть /Пер. 3 фр. Л. Кононович. - Львів, 2004.

[3] Гадамер Г.-Г. Актуальность прекрасного. - М., 1991.

[4] Козловський П. Постмодерна культура: суспільно-культурні наслідки технічного розвитку // Сучасна зарубіжна філософія. Течії і напрями. Хрестоматія /Упор. В.В.Лях, В.С. Пазенок. - К., 1996.

[5] Кримсъкий С.Б. Запити філософських смислів. - К., 2003.

[6] Рікъор П. Про інтерпретацію // Після філософії: кінець чи трансформація? - K., 2000. 